\title{
Safflower (Carthamus tinctorius L.): An underutilized crop with potential medicinal values
}

\author{
Sunil S. Gomashe», Krishnananda P. Ingle, Yukta A. Sarap, Dinesh Chand and S. Rajkumar* \\ ICAR-National Bureau of Plant Genetic Resources, Regional Station, Akola, Maharashtra-444 104, India \\ *ICAR-National Bureau of Plant Genetic Resources, Pusa Campus, New Delhi-110012, India
}

\section{Article Info}

Article history

Received 25 April 2021

Revised 13 June 2021

Accepted 14 June 2021

Published online 30 June 2021

\section{Keywords}

Safflower

Pharmaceutical values

Carthamin

Hydroxysafflor yellows A

Hydroxysafflor yellows B

\begin{abstract}
Safflower (Carthamus tinctorius L.), is cultivated mainly for its seed, which is used for the extraction of high quality edible oil. Traditionally, the crop is grown for its flowers, used for paint industry, textile industry, flavouring foods and making dyes. Safflower is used as cut flowers and also having pharmaceutical potential for the treatment of male and female infertility, cardiovascular diseases, reduction in the blood glucose level, treatment of cancer and reduction in the plasma cholesterol level, etc. Despite having such significant potency, the crop has remained minor, neglected and underutilized. Therefore, there is a need of scientific community to focus the research on this crop and make it popularize as a commercial crop with various values added products. Safflower contains numerous chemical components (secondary metabolites) that possess anticoagulant, antioxidant activities and other human health benefits with pharmacological importance such as treatment against cardiac, reproductive and gastrointestinal diseases. Research should be focused on the development of spineless varieties with high oil contents. With all these merits, safflower genetic improvement required to be taken up for enhancing overall productivity and income per unit area. This review provides a brief insight in to the safflower crop biology, related species, world production scenario, its phytomedicinal properties and applications, production constraints and future strategies for its overall improvement.
\end{abstract}

\section{Introduction}

Safflower (Carthamus tinctorius $\mathrm{L}$.) is an oilseed crop, having $2 \mathrm{n}=24$ chromosomes and belongs to the family Compositae or Asteraceae. Carthamus is the latinized synonym of the Arabic word quartum, or gurtum, which means the dye color extracted from safflower flowers (Singh and Nimbkar, 2006). An underutilized crop defined as those domesticated species whose genetic potential has been unraveled and having "larger biodiversity portfolio" or genetic diversity but underused for the commercial cultivation (Padulosi and HoeschleZeledon, 2004). Such species offers viable agricultural alternatives in response to climate change and are adapted to cultivation on the marginal lands. Thus, it provides additional option for generating the income to farmers and agricultural businesses (Mayes et al., 2012; Thies, 2000). Safflower, a diversified crop has been extensively grown in India, mostly for its quality oil rich in polyunsaturated fatty acids (linoleic acid) and for the carthamin (orange-red dye), extracted from the brilliantly colored flowers. Safflower flowers are commercially exploited for the herbal preparations in China and having medicinal and culinary properties ( $\mathrm{Li}$ and Mundel, 1996). The dried flower petal (Carthamiflos) is a valued drug in traditional Chinese medicine

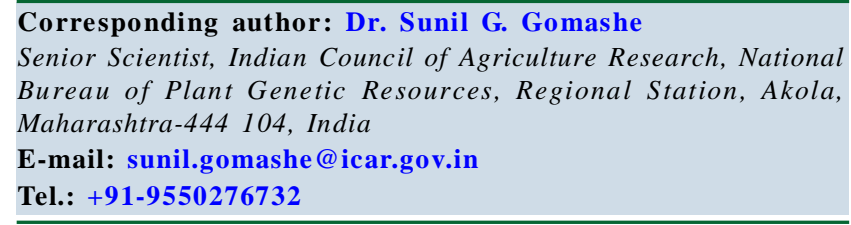

Copyright () 2021 Ukaaz Publications. All rights reserved.

Email: ukaaz@yahoo.com; Website: www.ukaazpublications.com and has been used clinically for the prevention and treatment of cardiovascular diseases (Guo et al., 2017). Though, crop having tremendous genetic potential and great exploitation for various purposes, the area under safflower around the world is diminishing due to lack of information on its improved crop management practices, other competitive crops, global import export policies and value-added product development from it. The research and development on different aspects of safflower, despite its adaptability to varied growing conditions with very high yield potential and diversified uses of different plant parts, have not received due attention. This probably is the main reason for its negligence and as a minor crop around the world in terms of area and production, compared to the other oilseed crops. However, interest has been rekindled in this crop in past few years due to three main reasons; scanty rainfall leads a huge shortfall of oilseed production in the country to which safflower is most suited and withstand in limited availability of water; consumers preference for healthy oil with less amounts of saturated fats for which safflower is well known; and herbal medicinal properties and extraction of edible dyes from flowers to which safflower is mainly recognized. Each and every plant parts of the safflower have utility either as a food or a phytomedicine.

\subsection{World's distribution and production}

Safflower has a long history of cultivation for hundreds of years from China to the Mediterranean region and all along the Nile valley spanning up to Ethiopia (Weiss, 1971). Presently it's grown 
commercially in India, United States of America, Mexico, Ethiopia Kazakhstan, Australia, Argentina, Uzbekistan, China, and Russian Federation. Pakistan, Spain, Turkey, Canada, Iran, and Israel also grow safflower to a limited extent. Historically, safflower acreage and production around the world have witnessed wide fluctuations in the past. Safflower seed production in the world rose from 487,000 tonnes in the year 1965 to $1,007,000$ tonnes in 1975 , and subsequently, it decreased to 921,000 tonnes in 1985 (Anonymous, 2002). Mexico was the most important producer of safflower in the world until 1980, when it occupied an area of 528,000 ha with a production of above 600,000 tonnes during the year 1979-1980. However, the production of safflower in Mexico decreased significantly in later years, becoming only $10 \%$ of the worlds production recorded for the year 1979-1980 (Cervantes-Martinez, 2001). Commercial production of safflower in the United States of America was started during 1950s, and therefore, the area rapidly increased to 175,000 ha mainly in the states of California, Nebraska, Arizona, and Montana. Safflower in China occupied an area from 35,000 to 55,000 ha, producing $50 \mathrm{MT}$ to $80 \mathrm{MT}$ seeds annually. Xinjiang was the largest safflower producer state, which accounted for $80 \%$ of total safflower production in China (Zhaomu and Lijie,
2001).World's safflower seed production was about 627,653 tonnes in the year 2018. This was decreased by about $17.7 \%$ compared to the previous year and if it is compared to production 10 years ago, it was decreased by $1.72 \%$ (Anonymous, 2020a). In the year 2019, Kazakhstan was the top country by safflower seed production among 13 countries. Safflower seed production in Kazakhstan was 199,789 tonnes that accounts for $34.87 \%$ of total safflower seed production in the World. The top five countries (Kazakhstan, United States of America, Russian Federation, Mexico, and China) accounted for $79.23 \%$ of it. The total safflower seed production was estimated at 572,879 tonnes in 2019 (Anonymous, 2020b). The world's top safflower-producing countries in 2019 are depicted in Figure 1. The safflower area in India in the year 2004-2005 was 387,000 ha, with a production of 154,000 tonnes of seed (Anonymous, 2004). Presently, it has come down to 24,640 tonnes. In India, Maharashtra and Karnataka states occupied about $72 \%$ area and have produced about $24 \%$ safflower seeds. Along with these two states, other safflower producing states in India are Andhra Pradesh, Odisha, Madhya Pradesh, Chhattisgarh, and Bihar. Safflower production in India is usually confined to rain-fed farming during post rainy season.

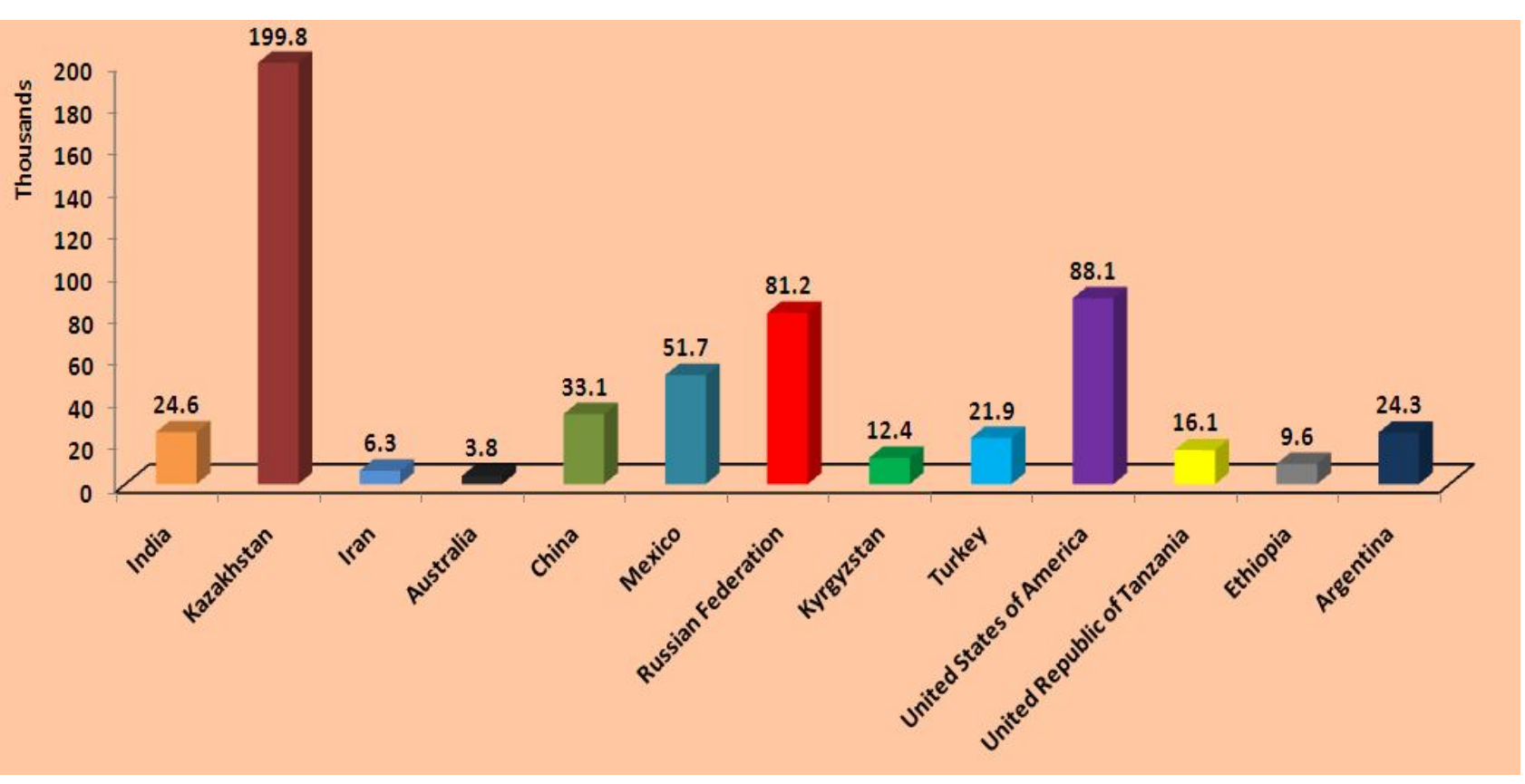

Figure 1: World's top safflower-producing (in thousand tonnes) countries in 2019.

\subsection{Cultivated safflower and its relatives}

Cytogenetic studies led by Imrie and Knowles (1970) and Khidir and Knowles (1970) suggest that Carthamus palaestinus, a selfcompatible wild species restricted to the deserts of southern Israel and western Iraq (Zeven and Zhukovsky, 1975), with white and yellow flowered forms, is the progenitor from which derived the weedy species $C$. oxyacanthus, a mix of self-compatible and selfincompatible types, and $C$. persicus Wild., a self-incompatible species. These successively are considered the parental species of the cultivated species C. tinctorius L. (Ashri and Knowles, 1960). These four reported safflower species represent the genome denoted as "BB" with chromosome number $2 \mathrm{n}=24$. These can be intercrossed in all combinations to produce fertile hybrids (Knowles, 1959). Due to similarity in chromosome number in these species, there is a complete chromosome pairing in hybrids which is not often noticed where parental species differ in chromosome numbers (Ashri and Knowles, 1960). Introgression of the weedy and cultivated species should be taken up to improve the cultivated safflower (Zeven and Zhukovsky 1975). The weedy progenitors of cultivated safflower are cosmopolitan within the areas where safflower is grown.

Carthamus oxyacanthus, a branchy, very spiny and annual weed is a very serious common weed of Pakistan and Northwest India (Ashri and Knowles, 1960). Seeds contain approximately $28 \%$ oil and can be used for culinary purposes and as lighting fuel (Weiss, 1983). 
Seeds are mostly small and black with no pappus. Carthamu spersicus is additionally a really serious weed, in Syria, Lebanon and Turkey (Knowles, 1959) with light yellow to orange flowers. Outer involucral bracts are narrow and extend beyond the top (Ashri and Knowles,1960).

\subsection{Production issues}

Safflower is a day length-neutral, long-day plant. During the emergence, first few leaves after a frost show little bit injury but plant compensate over it and grow quite normally. But, frost can cause substantial damage to crop during the elongation phase. As plant develop and bears flowers, this frost at the other end of the plant's development, lower oil content and yield level and sometime lead seed death (Mündel et al., 1992). Safflower is a poor competitor with weeds, most of the weeds become taller than the safflower crop and competes for the nutrition, sunlight and soil moisture, which effectively shed the crop and lower the yield. Weeds can cut safflower yields greatly and can cause complete crop losses (Dajue and Mundel, 1996). Very few chemical herbicides are registered in safflower for pre-plant incorporation to control a variety of grass and weeds. Seeding safflower into a firm moist seedbed not only enhances its emergence and stand, but also improves vigor and allows the crop to compete more effectively with weeds (Dajue and Mundel, 1996). Safflower owing to its good tolerance level to drought and heat because of deep taproot and xerophytic attribute of spines; does not survive in case of standing water conditions for a few hours in warm weather when the temperature goes above $20^{\circ} \mathrm{C}$ and led a rapid spread of soil borne pathogens such as Pythium and Phytophthora (Rubis, 1981). This ultimately leads to the plant death (Mündel et al., 1995). Safflower attains maximum yield in deep fertile, well drained and sandy loamy soil and reduce the germination and seedling emergence in heavy clay soils. Prolonged and heavy rainfall during the flowering interferes the seed setting and pollination in the safflower. Also, lead to pollen shedding as the temperature moves above $32^{\circ} \mathrm{C}$ (Mündel $e t$ al., 1992).

\section{Safflower importance and potential}

\subsection{Whole plants}

Safflower use for the herbal preparation (from safflower blossom) and tea to overcome the infertility/sterility and abortion issues in women and are mostly consumed in India and Afghanistan (Weiss1983; DajueLi and Han Yuanzhou, 1993). The products from all safflower plant are sold in India and Pakistan as 'pansari' to treat various ailments. Safflower young leaves used as curry or dishes, and as a salad in India, Burma and Pakistan.Spineless varieties have been used as cut flowers in Latin America, Japan and Western Europe.

\subsection{Flowers}

\subsubsection{Food colour and cosmetics}

For saffron, the most popular and costly spice in the world safflower dried florets are used as a common adulterant. In restaurants, sauces, pickles, bread and rice soups take on a yellow to orange colour from the florets. Kunming in Yunnan Province in China is having large factory for the production of dyes from carthamin. It is mixed with French chalk, and in Japanese cosmetics, it is used in the preparation of lipstick (Smith, 1996).

\subsubsection{Dyes}

Safflower florets are mostly extracted for the preparation of carthamidin (water soluble yellow coloured dye) and carthamin (water-insoluble red dye), having solubility in alkali. Florets contain 0.3-0.6\% carthamin (Weiss, 1971; 1983).

\subsubsection{Pharmacological application}

In China, the consumption of safflower is more to prevent most of the serious illness and health related issues. Usually, safflower has bitter taste. The Institute of Botany of the Chinese Academy of Sciences in Beijing has successfully developed a non-bitter tea having sweet smell and which also contains amino acids, minerals and vitamins $B_{1}, B_{2}, B_{12}, C$ and $E$ (Weiss, 1971). The active and main ingredient in the safflower is water soluble yellow coloured pigment "carthamidin" having medicinal values to treat the cardiovascular disease, menstrual problems, and swelling associated with trauma. Recently, carthamin and carthamidin pigments have been used for cosmetic coloring, such as face andhair cream, and shampoo and body lotion (Mani et al., 2020).

Safflower remarkably shows purgative, analgesic and antipyretic characteristics, and is useful in patients with poisoning (Delshad et al., 2018). Safflower extracts from flowers and seeds having different pharmacological importance and use for the development of the drugs. Safflower also contains anti nutritional factors (ANFs)/ compounds in the form of tannins, acacetin, serotonin and luteolin and which have anticoagulant, antioxidant, antibacterial and antiinflammatory activities and are associated with reduction in the blood glucose level, treatment of cancer and reduction in the level of plasma cholesterol (Singhal et al., 2018; Huang et al., 1999; Duarte et al., 2001; Dajas et al., 2003; Benavente-García andCastillo, 2008; Lin et al., 2008). Safflower decoctions have been used successfully for treatment of male sterility (Qin Yuehao, 1990) and dead sperm excess disease (Qu Chun, 1990). Safflower reduces hypertension, dilates arteries and increases blood flow and, hence oxygenation of tissues (Deng, 1988; Wang Guimiaoand Yili, 1985). Safflower, along with other herbs, has been used to treat respiratory diseases (whooping cough) and chronic bronchitis (Wang Guimiao and Li Yili, 1985). Hydroxysafflor yellow A and B (HSYA and HSYB) extracted from flowers elicit varied inflammatory response, including proliferation and inflammatory responses of human fetal lung fibroblasts (Liu $e t$ al., 2019), and an asthma-related inflammatory response in human bronchial smooth muscle cells (HBSMCs) (Guo et al., 2019). Safflower eye drops reduce myopia, especially in children (Wang Guimiao and Li Yili, 1985). Safflower seeds and extracts have been used to stimulate bone formation and preclude the osteoporosis occurrence (Alkhafaji et al., 2020). The pharmaceutical importance of safflower metabolites/extracts enlisted in Table 1. 
Table 1: List of safflower metabolites/extracts and their uses in the pharmacology

\begin{tabular}{|c|c|c|c|c|c|}
\hline Biological activity & $\begin{array}{l}\text { Safflower } \\
\text { plant } \\
\text { parts }\end{array}$ & Active compound & $\begin{array}{l}\text { Biological/ } \\
\text { lab model } \\
\text { for testing }\end{array}$ & Observed activity & References \\
\hline \multirow{3}{*}{$\begin{array}{l}\text { Anti-inflammatory } \\
\text { effect }\end{array}$} & Flower & $\begin{array}{l}\text { Hydroxysafflor } \\
\text { yellow A }\end{array}$ & Human & $\begin{array}{l}\text { It leads the activation of human bronchial } \\
\text { smooth muscle cells and also inhibits } \\
\text { platelet-activating factor (PAF) which } \\
\text { leads the pro-inflammation }\end{array}$ & Guo et al., 2019 \\
\hline & Flower & Carthamin yellow & Rat & $\begin{array}{l}\text { It leads complete reduction of ischemia- } \\
\text { reperfusion injury }\end{array}$ & Lu et al., 2019 \\
\hline & Flower & $\begin{array}{l}\text { Hydroxysafflor } \\
\text { yellow B }\end{array}$ & Rat & $\begin{array}{l}\text { Brain protection against cerebral ischemia } \\
\text { reperfusion injury }\end{array}$ & Du et al., 2019 \\
\hline \multirow{4}{*}{ Anticancer effect } & Flower & $\begin{array}{l}\text { Safflower } \\
\text { polysaccharide }\end{array}$ & Human & $\begin{array}{l}\text { It inhibits metastasis and the proliferation } \\
\text { of breast cancer cell }\end{array}$ & Luo et al., 2015 \\
\hline & Flower & $\begin{array}{l}\text { Hydroxysafflor } \\
\text { yellow B }\end{array}$ & Human & Reduces the growth of cancerous cells & Qu et al., 2019 \\
\hline & Seed & $\begin{array}{l}\text { Fatty acid and } \\
\text { phytic acid }\end{array}$ & Rat & $\begin{array}{l}\text { Anticancer activity against HEPG } 2 \text { cancer } \\
\text { cell line }\end{array}$ & Doha et al., 2019 \\
\hline & Seed & Seed extract & In vitro & $\begin{array}{l}\text { Inhibitory effect of the safflower seed } \\
\text { (SS) on the proliferation of human } \\
\text { colorectal cancer cells }\end{array}$ & Jeong et al., 2016 \\
\hline \multirow{3}{*}{ Antioxidant effect } & Seed & Seed granular tea & Human & $\begin{array}{l}\text { Antioxidant activity and potential effects } \\
\text { in postmenopausal women }\end{array}$ & Cho et al., 2011 \\
\hline & Flower & Carthamus red & Rat & $\begin{array}{l}\text { Antioxidant and protection against } \\
\text { hepatitis to lowered the induction of liver } \\
\text { damage }\end{array}$ & Wu et al., 2013 \\
\hline & Seed & $\begin{array}{l}\text { Serotonin } \\
\text { derivatives }\end{array}$ & In vitro & $\begin{array}{l}\text { Strong radical scavenging activity and } \\
\text { lipid peroxidation }\end{array}$ & Khalid et al., 2017 \\
\hline \multirow[b]{2}{*}{ Osteoporosis effect } & Seed & Seed oil & Rat & Improves osteoporosis & Alam et al., 2006 \\
\hline & Seed & Seed oil & Rat & $\begin{array}{l}\text { Safflower seeds and extracts stimulate the } \\
\text { differentiation of osteoblasts and promote } \\
\text { speedy recovery in bone fracture incidents }\end{array}$ & Khalid et al., 2017 \\
\hline \multirow{3}{*}{$\begin{array}{l}\text { Brain and liver } \\
\text { disease effect }\end{array}$} & Flower & $\begin{array}{l}\text { Hydroxysafflor } \\
\text { yellow A }\end{array}$ & Rat & $\begin{array}{l}\text { Potential treatment for hepatic fibro } \\
\text { genesis }\end{array}$ & Dong et al., 2013 \\
\hline & Seed & Seed powder & Rat & $\begin{array}{l}\text { Safflower seeds powder possessed } \\
\text { cytotoxicity against hepatocarcinoma cell } \\
\text { line HEPG } 2 \text { and afford hepato-protection } \\
\text { against non-alcoholic fatty liver disease } \\
\text { (NAFLD) }\end{array}$ & Doha et al., 2019 \\
\hline & Seed & Oil & Rat & $\begin{array}{l}\text { Reduction in plasma and hepatic total- } \\
\text { cholesterol, plasma triglycerides, and } \\
\text { atherogenic index }\end{array}$ & Moon et al., 2001 \\
\hline \multirow{2}{*}{$\begin{array}{l}\text { Cell proliferation } \\
\text { and inhibition } \\
\text { effect }\end{array}$} & Seed & $\begin{array}{l}\mathrm{N}-(p \text {-Coumaroyl }) \\
\text { serotonin }\end{array}$ & Human & $\begin{array}{l}\text { Grows the proliferation of normal human } \\
\text { andmouse fibroblasts }\end{array}$ & Takii et al., 1999 \\
\hline & Flower & Flower extract & Rat & Effective against diabetes & Asgary et al., 2012 \\
\hline
\end{tabular}

\subsection{Safflower seed utilization in food industries}

Over the years there have been many studies conducted to increase the utilization of safflower seed as food and value added products. The safflower finely ground seed paste is use to enhance the cheese and curd formation in Iran (Knowles, 1965).By using safflower seed enzymes as an experimental substitution for rennin, a white cheese having pleasant smell and good softness was produced (Smith, 1996).Roasted seeds, generally mixed with chickpeas, barley or wheat, are eaten as a snack food in Ethiopia and Sudan (Belayneh and Wolde-Mariam, 1991). 


\subsection{Safflower oil composition and its uses}

Safflower in the whole world is primarily grown for its edible oil, margarine and salad oil. Oilseeds are some of the major sources of vegetable oils used primarily for nutritional, industrial and pharmaceutical applications, as determined by their fatty acid composition and these composition varied as per plant speciesand the environmental effects (Anjani and Yadav, 2017). It has been observed that Indian safflower cultivars (ISF1, ISF2, and ISF3) have high oleic acid content under irrigated conditions compared to rainfed crop (Anjani and Yadav, 2017). Safflower oil contains two main unsaturated fatty acids: oleic (18:1) and linoleic acid (18:2), which compose $90 \%$ of the total fatty acids. The remaining $10 \%$ includes saturated fatty acids like palmitic (16:0) and stearic acid (18:0). Standard safflower oil contains about 6-8\% palmitic acid, 2-3\% stearicacid, 16-20\% oleic acid, and 71-75\% linoleic acid (Liu et al., 2016). The potential uses of different parts of safflower are depicted in Figure 2.

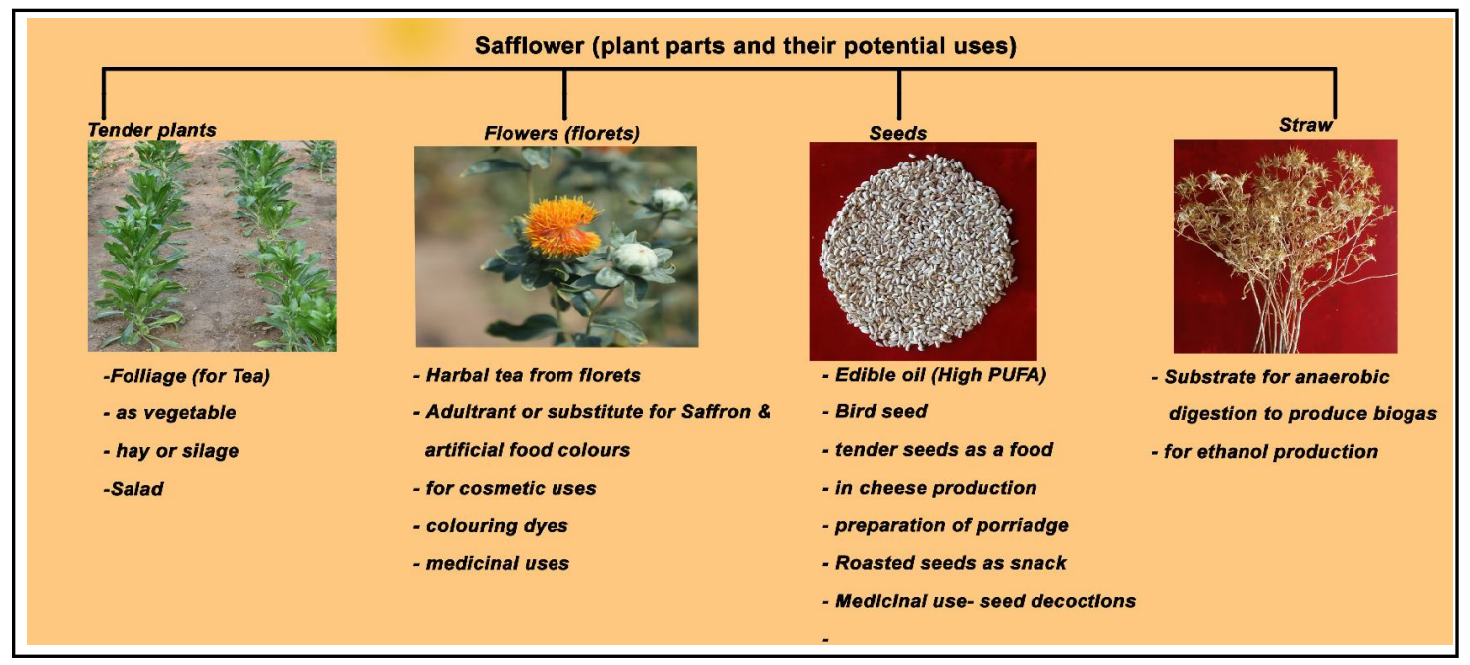

Figure 2: Safflower plant parts and their potential uses.

\section{Constraints in safflower production}

The major constraints such as, low per-hectare yields associated with low harvest index, and low seed-oil contents, presence of spines, research should be focused on the development of spineless high yielding varieties with high oil content. Also, lack of assured market and price support; absence of demand for safflower seed and oil in non-traditional areas, lack of awareness about region-specific agroproduction technologies which do not led the full exploitation of yield potential of safflower. Also, the susceptibility of crops to pests, major fungal and bacterial diseases and abiotic stresses (mostly drought and salinity concerns) contributed to less safflower production. The processing facilities should be there at the production centers within reasonable distances (Dajue and Mundel, 1996).

\section{Future directions}

Flower yield and pigment content of the flowers are the other traits that have gained economic importance recently, due to an increasing demand for safflower flowers as a source of natural food color in European and other Western countries and their use in medicines for curing several chronic diseases. No attention has been paid to improvement of these traits in safflower. The improvement in yield of flowers and pigments in flowers would certainly help in increasing total remuneration from the crop to the farmer. Also, exploiting genetic diversity for the improvement of safflower through marker assisted breeding of QTLs/genes associated with agronomical traits. Therefore, genetic modification of safflower would be of enormous importance in improving productivity, production, and remuneration per unit area from the crop, which in turn would certainly help in increasing safflower area in the world.

\section{Conclusion}

Safflower has significant uses and having pharmacological, industrial and culinary properties. Despite this, the crop has remained minor. Therefore, a need to create awareness about the usefulness of this economically important underutilized and neglected crop is of paramount importance. The scientists should focused this crop and develop multidisciplinary research projects to address issues related to pest and disease, morphological ideotypes, agronomical traits, developmental pattern, etc., through genetic manipulation, productrelated research to elucidate the importance of effectiveness of safflower cropfor a pharmacological uses.

\section{Acknowledgements}

The authors are thankful to the Department of Biotechnology, New Delhi, India, for funding project on Safflower crop improvement.

\section{Conflicts of interest}

The authors declare that there are no conflicts of interest relevant to this article.

\section{References}

Alam, R.; Kim, S.M.; Lee, J.I.; Chon, S.K.; Choi, S.J.; Choi, I.H. and Kim, N.S. (2006). Effects of safflower seed oil in osteoporosis induced Ovariectomized Rats. Am. J. Chin. Med., 34:601-612.

Alkhafaji, S.L.; Kashamar, A.M. and Alkhafaji, I.H. (2020). Chemical composition and antimicrobial activity of different solvent extracts of Carthamus tinctorius flowers. Research J. Pharm. and Tech., 13(12):6055-6060.

Anjani, K. and Yadav, P. (2017). High yielding-high oleic non-genetically modified Indian safflower cultivars. Ind. Crop. Prod., 104:7-12. 
Anonymous (2002). Safflower Research in India. Directorate of Oilseeds Research, Hyderabad, pp:96.

Anonymous (2004). Annual Progress Report (2004-2005) AICRP on Safflower. Directorate of Oilseeds Research, Rajendranagar, Hyderabad-500 030, India, pp:181

Anonymous (2020a). https://www.helgilibrary.com/charts/whichcountry-produces-the-most-safflower-seeds

Anonymous (2020b). https://knoema.com/FAOPRDSC2020/productionstatistics-crops-crops-processed.

Asgary, S.; Rahimi, P.; Mahzouni, P. and Madani, H. (2012) Antidiabetic effect of hydroalcoholic extract of Carthamus tinctorius L. in alloxan-Induced diabetic rats. J. Res. Med. Sci., 17:386392.

Ashri, A. and Knowles, P.F. (1960). Cytogenetics of safflower (Carthamus L.) species and their hybrids. Agron. J., 52:11-17.

Belayneh, H. and Y. Wolde-Mariam. (1991). Safflower production, utilization and research in Ethiopia. pp:43-55 in Proceedings Second International Safflower Conference, Hyderabad, India, 9-13 Jan. 1989 (V. Ranga Rao and M. Ramachandran, eds.). Indian Society of Oilseeds Research, Directorate of Oilseeds Research, Hyderabad, India.

Benavente-García, and 0, Castillo. (2008). Update on uses and properties of citrus flavonoids: New findings in anticancer, cardiovascular and anti-inflammatory activity. J. Agric. Food Chem., 56:61856205 .

Cervantes-Martinez, J.E.; Rey-Ponce, M. and M. Velazquez-Cagal. (2001) Evaluation of accessions from worldvcollection of safflower for Alternaria incidence and seed oil content. In Proceedings of the $\mathrm{v}^{\text {th }}$ International Safflower Conference, Williston, ND, and Sidney, MT, July 23-27, Bergman, J.W. and H.H. Mundel, Eds., pp:163.

Cho, S.H.; Jang, J.H.; Yoon, J.Y.; Han, C.D.; Choi, Y. and Choi, S.W. (2011) Effects of a safflower tea supplement on antioxidative status and bone markers in postmenopausal women. Nutr. Res. Pr., 5:20-27.

Dajas, F.; Rivera, F.; Blasina, F.; Arredondo, F.; Echeverry, C.; Lafon, L.; Morquio, A. and Heizen, H. (2003). Cell culture protection and in vivo neuroprotective capacity of flavonoids. Neurotox. Res., 5:425432.

Dajue, Li. and Mündel, H.H. (1996). Safflower. Carthamus tinctorius L. promoting the conservation and use of underutilized and neglected crops. Institute of Plant Genetics and Crop Plant Research, Gatersleben/International Plant Genetic Resources Institute, Rome, Italy. ISBN 92-9043-297-7.

Dajue, Li. and Yuanzhou, H. (1993). The development and exploitation of safflower tea. pp:837-843. In: Proceedings of the Third International Safflower Conference, Beijing, China, 9-13 June 1993 (Li Dajue and Han Yunzhou, eds.). Beijing Botanical Garden, Institute of Botany, Chinese Academy of Sciences.

Delshad, E.; Yousefi, M.; Sasannezhad,P.; Rakhshandeh, H. and Zahra, A. (2018) Medical uses of Carthamus tinctorius L. (Safflower): A comprehensive review from traditional medicine to modern medicine. Electr. Physician, 10(4):6672-6681.

Deng, Y. (1988). Observation on the recent curative effect of the traditional Chinese medicine invigorating the circulation of blood plus anticarcinogen for treatment of acute leukemia. J. Comb. Trad. Chinese Western Med., 4:717-719.

Doha, A.M.; Fouda, K.A. and Rasha, S.M. (2019). In vitro anticancer activity of quinoa and safflower seeds and their preventive effects on non-alcoholic fatty liver. Pakistan J. Biol. Sci., 22:383-392.
Dong, H.; Liu,Y.; Zou, Y.; Li, C.; Li, L.; Li, X.; Thao, X.; Zhou, L.; Liu, J. and Niu, Y. (2013). Alteration of the ERK5 pathway by hydroxysafflor or yellow A blocks expression of MEF2C in activated hepatic stellate cells in vitro: Potential treatment for hepatic fibrogenesis. Pharm. Biol., 52:435-443.

Du, S.; Deng, Y.; Yuan, H. and Sun, Y. (2019). Safflower yellow B protects brain against Cerebral Ischemia reperfusion injury through AMPK/ NF-kB Pathway. Evid. Based Complement. Altern. Med., 19:7219740.

Duarte, J.; Pérez-Palencia, R.; Vargas, F.; Ocete, M.A.; Perez-Vizcaino, F.; Zarzuelo, A. and Tamargo, J. (2001). Antihypertensive effects of the flavonoid quercetin in spontaneously hypertensive rats. Br. J. Pharmacol., 133:117-124.

Guo, D.; Xue Y.; Li D.; He B.; Jia X.;, Dong, X. and Guo, M. (2017). Over expression of CtCHS1 increases accumulation of quinochalcone in safflower. Front. Plant Sci., 8:1409.

Guo, X.; Zheng, M.; Pan, R.; Zang, B.; Gao, J.; Ma, H. and Jin, M. (2019). Hydroxysafflor yellow A (HSYA) targets the platelet-activating factor (PAF) receptor and inhibits human bronchial smooth muscle activation induced by PAF. Food Funct., 10:4661-4673.

Huang, Y.; Hwang, J.; Lee, P.; Ke, F.; Huang, J.; Huang, C.; Kandaswami, E.M., Jr and Lee, M. (1999). Effects of Luteolin and Quercetin inhibitors of tyrosine kinase on cell growth and metastasis:Associated properties in $\mathrm{A} 43 \mathrm{Al}$ cells over expressing epidermal growth factor receptors. Braz. J. Pharmacol., 128:999-1010.

Imrie, B.C. and Knowles, P.F. (1970). Inheritance studies in interspecific hybrids between Carthamus flavescens and $C$. tinctorius. Crop Sci., 10:349-352.

Jeong, J.B.; Gwang, P. and Hong, S. (2016). Anticancer activity of the safflower seeds (Carthamus tinctorius L.) through inducing cyclin D1 proteasomal degradation in human colorectal cancer cells. Korean J. Pl. Res., 29:10.7732/kjpr.2016.29.3.297.

Khalid, N.; Khan, R. S.; Hussain, M. I.; Farooq, M.; Ahmad, A. and Ahmed, I. (2017). A comprehensive characterisation of safflower oil for its potential applications as a bioactive food ingredient: A review. Trends in Food Science and Technology, 66:176-186.

Khidir, O.M. and Knowles, P.F. (1970). Cytogenetic studies of Carthamus species (Compositae) with 32 pairs of chromosomes. II. Intersectional hybridization. Can. J. Genet. Cytol., 12:90-99.

Knowles, P.F. (1959). Plant exploration report for safflower and miscellaneous oilseeds: Near east and mediterranean countries, March-October 1958. Dept. of Agronomy, University of California, Davis, CA, in collaboration with USDA-ARS Crop Research Division, CR-43-5. [42 text p. plus photos.]

Knowles, P.F. (1965). Report of Sabbatic Leave, August 1, 1964-August 1, 1965. Report for University of California, Davis, CA. [48 text pp. plus numerous photos.]

Li, D. and Mundel, H.H. (1996). Safflower. Carthamus tinctorius L. promoting the conservation and use of underutilized and neglected crops. Institute of Plant Genetics and Crop Plant Research, Gatersleben/International Plant Genetic Resources Institute, Rome, pp:83.

Lin, C.W.; Hou, W.C.; Shen, S.C.; Juan, S.H.; Ko, C.H.; Wang, L.M. and Chen, Y.C. (2008). Quercetin inhibition of tumor invasion via suppressing PKC/ERK/AP-1-dependent matrix metalloproteinase-9 activation in breast carcinoma cells. Carcinogenesis, 29:1807-1815.

Liu, L.; Guan, L.L. and Yang, Y.X. (2016). A Review of fatty acids and genetic characterization of safflower (Carthamus tinctorius L.) seed oil. Org. Chem. Curr. Res., 5:160-163. 
Liu, S.; Wang, Y.; Wen, H.; Sun, X. and Wang, Y. (2019). Hydroxysa or yellow a inhibits TNF induced inflammation of human fetal lung fibroblasts via NFB signaling pathway. Evid. Based Complement. Altern. Med., pp: $1-9$.

Lu, Q.Y.; Ma, J.Q.; Duan, Y.Y.; Sun, Y.; Yu, S.; Li, B. and Zhang, G.M. (2019). Carthamin yellow protects the heart against ischemia/reperfusion injury with reduced reactive oxygen species release and inflammatory response. J. Cardiovasc. Pharm., 74:228-234.

Luo, Z.; Zeng, H.; Ye, Y.; Liu, L.; Li, S.; Zhang, J. and Luo, R. (2015). Safflower polysaccharide inhibits the proliferation and metastasis of MCF-7 breast cancer cells. Mol. Med. Rep., 11:4611-4616.

Mani, V; Lee, S.K.; Yeo, Y. and Hahn, B.S. (2020). A metabolic perspective and opportunities in pharmacologically important saffower. Metabolites, 10(253):1-18.

Mayes, S.; Massawe, F. J.; Alderson P.G.; Roberts J.A.; Azam-Ali, S.N. and Hermann, M. (2012). The potential for underutilized crops to improve security of food production. Jr. of Expt. Bot., 63:1075-1079.

Moon, K. D.; Back, S. S.; Kim, J. H Jeon, S. M.; Lee, M. K. and Choi, M. S. (2001). Safflower seed extract lowers plasma and hepatic lipids in rats fed high-cholesterol diet. Nutrition Research, 21(6):895-904. https:/ /doi.org/10.1016/S0271-5317(01)00293-7.

Mündel, H.H.; Huang, H.C.; Kozub, G.C. and Barr, D.J.S. (1995). Effect of soil moisture and temperature on seedling emergence and incidence of Pythium damping-off in safflower (Carthamus tinctorius L.). Can. J. Plant Sci., 75:505-509.

Mündel, H.H.; Morrison R.J.; Blackshaw, R.E. and Roth, B. (1992). Safflower production on the canadian prairies. Agric Canada Res. Station, Lethbridge/Alberta Safflower Growers Association with funding by Farming for the Future Project No. 87-0016, Alberta Agric. Research Institute. pp:35.

Padulosi, S. and Hoeschle-Zeledon, I. (2004). Underutilized plant species: What are they? Leisa Leusden, 20:5-6.

Qin, Y. (1990). An analysis on the clinical treatment of male sterility of 300 cases by kidney-benefited and invigorating blood-circulation decoction (in Chinese). Jiangxi Traditional Chinese Med., 21(3):21-22.

Qu, C. (1990). Clinical observation on dead sperm excess disease of 182 cases (in Chinese). Shanghai Traditional Chinese Med. Sci. J. 5:28-29.

Qu, C.; Zhu,W.; Dong, K.; Pan, Z.; Chen, Y.; Chen, X.; Liu, X.; Xu,W.; Lin, H. and Zheng, Q. (2019). Inhibitory effect of hydroxysafflor yellow B on the proliferation of human breast cancer MCF-7 Cells. Recent Pat. Anticancer Drug Discov., 14:187-197.
Rubis, D.D. (1981). Development of a root rot resistance in safflower by introgressive hybridization and thin-hull facilitated recurrent selection. pp: 205-209. In: Proceedings First International Safflower Conference, Univ. of Calif., Davis, California, USA, 12- 16 July (P.F. Knowles, ed.).

Singh, V. and Nimbkar, N. (2006). Safflower (Carthamus tinctorius L.). Genetic resources, chromosome engineering, and crop improvement, pp: 168 .

Singhal, G.; Singh, P.; Bhagyawant, S.S. and Srivastava, N. (2018). AntiNutritional factors in safflower (Carthamus tinctorius L.) seeds and their pharmaceutical applications. Int. J. Recent Sci. Res., 9:28859-28864.

Smith, J.R. (1996). Safflower. AOCS Press, Champaign, IL, USA. pp:624.

Takii, T.; Hayashi, M.; Hiroma, H.; Chiba, T.; Kawashima, S.; Zhang, H.L.; Nagatsu, A.; Sakakibara, J. and Onozaki, K. (1999). Serotonin derivative, $\mathrm{N}$-(p-Coumaroyl) serotonin, isolated from safflower (Carthamus tinctorius L.) oil cake augments the proliferation of normal human and mouse fibroblasts in synergy with basic fibroblast growth factor (bFGF) or epidermal growth factor (EGF). J. Biochem., 125:910-915.

Thies, E. (2000). Promising and underutilized species crops and breeds. Deutsche Gesellschaftfür Technische Zusammenarbeit (GTZ) GmbH, Eschborn, Germany.

Wang, G. and L. Yili. (1985). Clinical application of safflower (Carthamus tinctorius). Zhejiang J. Trad. Chinese Med., 20:42-43.

Weiss, E.A. (1971). Castor, Sesame and Safflower. Barnes and Noble, Inc., New York, Leonard Hill Books, London, pp:529-744.

Weiss, E.A. (1983). Oilseed crops. Chapter 6. Safflower. Longman Group Limited, Longman House, London, UK. pp:216-281.

Wu, S.; Yue, Y.; Tian, H.; Li, Z.; Li, X.; He,W. and Ding, H. (2013). Carthamus red from Carthamus tinctorius $\mathrm{L}$. exerts antioxidant and hepatoprotective effect against $\mathrm{CCl} 4$-induced liver damage in rats via the Nrf2 pathway. J. Ethnopharmacol., 148:570-578.

Zeven, A.C. and P.M. Zhukovsky. (1975). Dictionary of cultivated plants and their centres of diversity. Centre for Agric. Publ. and Document. (Pudoc), Wageningen, Netherlands, pp:219.

Zhaomu, W. and Lijie, D. (2001). Current situation and prospects of safflower products development in China. In Proceedings of the 5th International Safflower Conference, Williston, ND, and Sidney, MT, July 23-27, 2001. Bergman, J.W. and H.H. Mundel, Eds., pp:315-319.

Sunil S. Gomashe, Krishnananda P. Ingle, Yukta A. Sarap, Dinesh Chand and S. Rajkumar (2021). Safflower 